\title{
Objective selection of sensitive species indicative of pollution-induced change in benthic communities. 2. Data analyses
}

\author{
T. H. Pearson' ${ }^{1}$, J. S. Gray ${ }^{2}$ and P. J. Johannessen ${ }^{3}$ \\ ${ }^{1}$ Dunstafifnage Marine Research Laboratory, P. O. Box No. 3, Oban, Argyll, Scotland \\ ${ }^{2}$ Institutt for Marinbiologi, Universitetet i Oslo, P. O. Box 1064, Blindern, Oslo 3, Norway \\ ${ }^{3}$ Institutt for Marinbiologi, Universitetet i Bergen, 5065 Blomsterdalen, Norway
}

\begin{abstract}
An objective technique for identifying potential indicator species using analyses based on the distribution of individuals among species is presented. Benthic community data from 6 different areas in N. W. Europe are analysed. In each case species indicative of environmental change in the area are identified, even from areas where such changes are small and have resulted only in minor perturbations in the local community structure. It is shown that particular species groups are characteristically indicative of each area, and that ubiquitous indicator species common to many areas do not occur. The method is rapid and involves little computation; it is robust and can be used across a range of sample sizes; it is theoretically sound and allows the objective selection of species useful as indicators of pollutant effects.
\end{abstract}

\section{INTRODUCTION}

In an earlier paper (Gray and Pearson, 1982) a comparison was made of some of the more commonly used methods for the analysis of data from polluted marine benthic communities. An extension of the method was presented, based on the log-normal distribution of individuals among species (Gray and Mirza, 1979), as an objective technique for identifying those species in a community which were both sensitive to pollution effects and represented by sufficient numbers of individuals to be useful as indicator species. Analyses are given of a number of data sets to support the contention that this method provides a rapid and practical method for objectively identifying indicator species. Information from previously unpublished work in Loch Eil and the Firth of Clyde, Western Scotland and the Grimstadfjord - Nordåsvannet area, near Bergen in Southem Norway are presented, together with new analyses of published data from the North Sea (Dicks, 1976), Milford Haven, Pembrokeshire (Addy, 1976), and Mevagissey Bay, Cornwall (Probert, 1981). The relative utility of the proposed method in identifying species potentially indicative of polluted conditions is assessed in each case.
METHODS

We have used the method by Gray and Pearson (1982). Plots are made of the number of species on the ordinate against number of individuals per species in geometric classes on the abscissa. In order to give comparable scaling to the figures we use the percentage number of species. The scale of the geometric class can be varied, but we have followed Preston's (1962) $\times 2$ scale, i. e. Class $I=1$ individual per species, Class II $=2$ to 3 individuals per species, Class III $=4$ to 7 individuals per species, Class IV $=8$ to 15 individuals per species, etc. This plot usually shows half of a normal curve if the mode is not exposed or may, if the sample size is large, show a tendency to give 2 or 3 overlapping normal curves (see Gray and Pearson, 1982: Fig. 5). Ugland and Gray (1982) give the mathematical background for these curves.

Whether or not the distribution of individuals among species is a good fit to a log-normal or not is not a prerequisite for using the method since the primary goal is the detection of a number of species sensitive to pollution-induced stress. In fact the distribution may quite often tend towards a log series where the dominant number of species (the mode) is represented by 
Class I having 1 individual per species. The log-normal has the mode in Class II, III or higher, and Preston (1962) has shown how on taking a larger sample from the same community the mode moved to the right along the abscissa. A fit to the log series may be due to taking too small a sample from a log-normal distribution or be a real description of the data. In practice however, within the limits of the chi-square goodnessof-fit test there is usually no significant difference between the fit to both distributions. Using Occam's Razor therefore, we have opted for using the lognormal as an adequate descriptor of the distribution of individuals among species since it fits a wide variety of different ecological communities from lizards and butterflies to phytoplankton and birds (Krebs, 1972). Given that the log-normal (or more correctly the truncated log-normal, since the distribution is never a full normal curve) is to be expected in undisturbed communities, we expect the plots to show a more or less smooth right-hand half of a bell-shaped curve on the plots of number of species against individuals per species in geometric classes. As we believe that the log-normal is made up of series of log-normal distributions fused together (Ugland and Gray, 1982), the smoothness of the curve depends on the degree of fusion of the groups making up the full plot. If one subjects such a distribution to a disturbance in the form of organic matter which will allow some species to increase in abundance on utilization of the increased food resource then the groups of species formerly fused together now tend to move apart. Further increase in the amount of organic matter will result in a decrease in the total number of species with the mode being less high and the groups of species now becoming clearly evident and well separated. Fig. 5 in Gray and Pearson (1982) illustrates this trend. With increased organic enrichment, therefore, the smooth curve is changed to one representing a series of peaks.

The essential aspect of the proposed method is the identification of species useful in a monitoring context. Previous methods have relied on the ecological expertise of the investigator in identifying species that he or she deemed to be useful. Our method is objective in that we merely list those species that occur in what we term the second group of species to be revealed (Gray and Pearson, 1982; Fig. 5). The first group is that adjacent to the ordinate (geometric Classes I and II) and comprises the rare species represented by 1 or 2 to 3 individuals per sampling unit. These species usually constitute between 60 and $70 \%$ of the species in any given community (Ugland and Gray, 1982). Yet the reasons why a species is rare are many. Rareness may be due to random settlement or due to random predation or emigration or immigration, or to competition, or in fact to any physical factor that can influence a species. Explaining rareness is, therefore, we believe an impossible task. Hence we ignore the first group of species. The second group of species we define as those occurring in geometric abundance Classes $\mathrm{V}$ and VI (16 to 63 individuals per species and sampling unit). This definition of the second group has been arrived at pragmatically. Extensive study over a 10 yr period of a benthic community lead Pearson (1975) to identify a range of species typifying the changes observed, but based on his expertise as an ecologist. Application of the new method to the same data (Gray and Pearson, 1982) showed that the same species were revealed as those previously detected by subjective methods, (i. e. the experience of a practising ecologist). Thus although not relying on statistical methods to arrive at the species, the method is entirely objective since the investigator merely applies a technique and a list of species is obtained. The method is robust in that the exact form of the distribution involved does not matter (a log series or log-normal are equally acceptable) and the method is not much affected by varying sample size provided that this is over a certain minimum which in practice is probably at least 5 replicate $0.1 \mathrm{~m}^{2}$ grab samples per station.

The method concentrates on species of moderate abundance (16 to 63 individuals per species) rather than those comprising the third or fourth group, the commonest species. Whilst with heavy pollution some species become extremely dominant, the species involved are usually typical opportunistic species such as Capitella capitata or species of the genus Polydora in organically enriched areas. These species have as their characteristic large fluctuations in abundance over short time intervals since they respond rapidly to any form of disturbance. Monitoring of such species must take into account their potential for increase in individual numbers which can be from almost zero to over $400,000 \mathrm{~m}^{2}$ within $3 \mathrm{wk}$. If such species are selected for monitoring then sampling must be very frequent. However, many of these opportunistic 'species' are known or suspected to be complexes of closely related sibling species. C. capitata on the U.S. east coast comprises at least 6 species, all anatomically very similar yet differing in life-history characteristics and distinguishable by gel electrophoresis (Grassle and Grassle, 1976). In Oslofjord, C. capitata represents in fact 3 sibling species and there are other closely related capitellid genera (Mediomastus and Heteromastus) which require detailed microscopy in order to distinguish them (Tarjem, pers. comm.). There are also 6 species of Polydora in Oslofjord (Ramberg, pers. comm.). To determine the species composition of a sample of very dense opportunistic species is rarely attempted; more usually these groups of species are recorded as capitellids and spionids. Other species 
typical of organically very enriched areas, such as the oligochaete Peloscolex benedeni and the polychaete Heteromastus filiformis, probably also represent complexes of species which we have reason to believe will also show quite different life-history characteristics among the siblings. A further difficulty with these species is that many of them live inside tubes or are coated in mucous and sediment. Separating organism from adhering sediment is extremely time consuming. For these reasons we do not recommend the use of the commonest species in monitoring programmes. In the following analyses we hope to demonstrate that the species comprising Group 2 (geometric Classes $V$ and VI) do give a rationalized list of species which show clearly the trends in data sets. We put forward this method as an additional tool which may help to rationalize the lists of species involved in monitoring programmes from 100 to 200 down to a manageable 10 to 20 .

\section{LOCH EIL, SCOTLAND}

The first part of this communication (Gray and Pearson, 1982) provided a detailed analyses of data from Loch Eil published in 1975 and showed that the number of individuals per species plotted as geometric classes against the number of species in each class identified the incipient spread of abundance groups following a pollution-related distortion of the community. Moreover a closer analysis of those species constituting the classes where change is most rapid along a spatial or temporal pollution gradient (usually geometrical Classes $\mathrm{V}$ and $\mathrm{VI}$ ) revealed a close correspondence between these species and those subjectively identified as typifying initial and later stages of pollution. The data analysed were drawn from the deep basin of Loch Eil, the area most radically affected by pollution from a pulp and paper mill which first discharged to the loch system in 1966 (Pearson, 1975). Data have been collected regularly in the same area and in other areas of the same system in subsequent years, and a further test of the practicality and objectivity of the suggested analytical method will be to examine these later data sets to see if the same suite of indicator species is suggested.

In 1975-76 an intensive sampling programme was carried out at 3 stations in Loch Eil and at a control station outside the Loch system. During this period three $0.1 \mathrm{~m}^{2}$ grab samples were taken at each station at 12 monthly intervals; the results have recently been detailed by Pearson (1982a, b). Consistent differences in the faunal composition at each of the 4 stations were shown to be a consequence of the relative level of organic pollution, which differed in each area. The

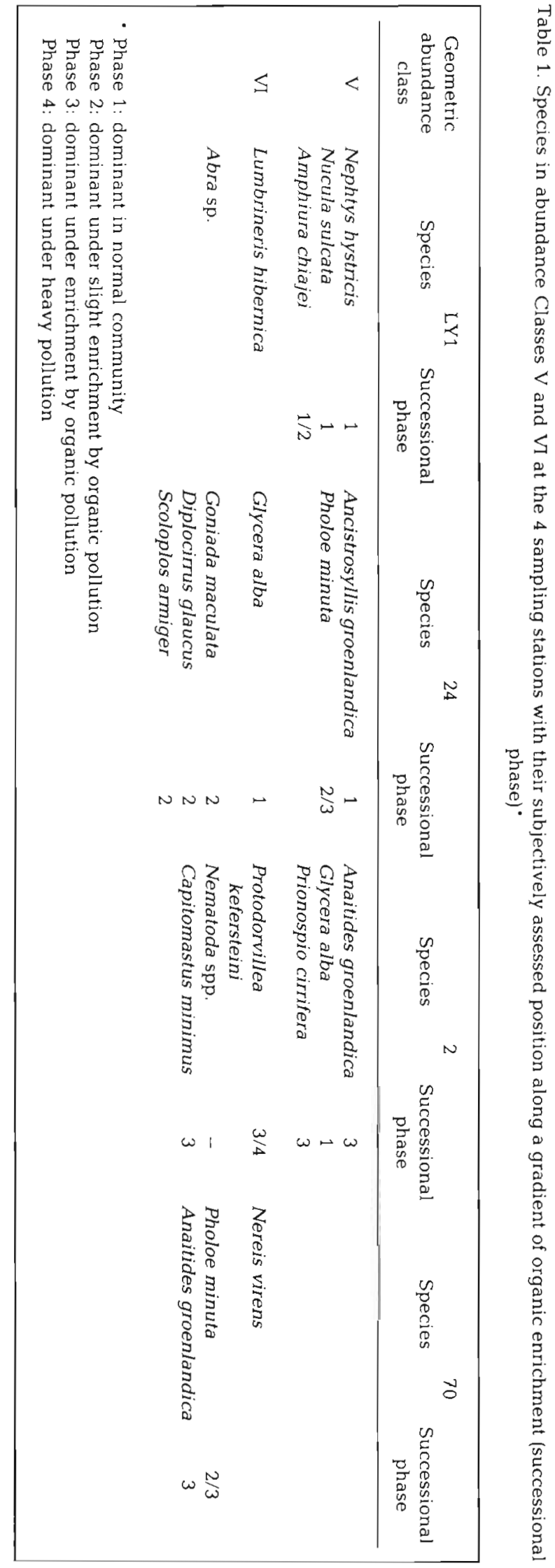




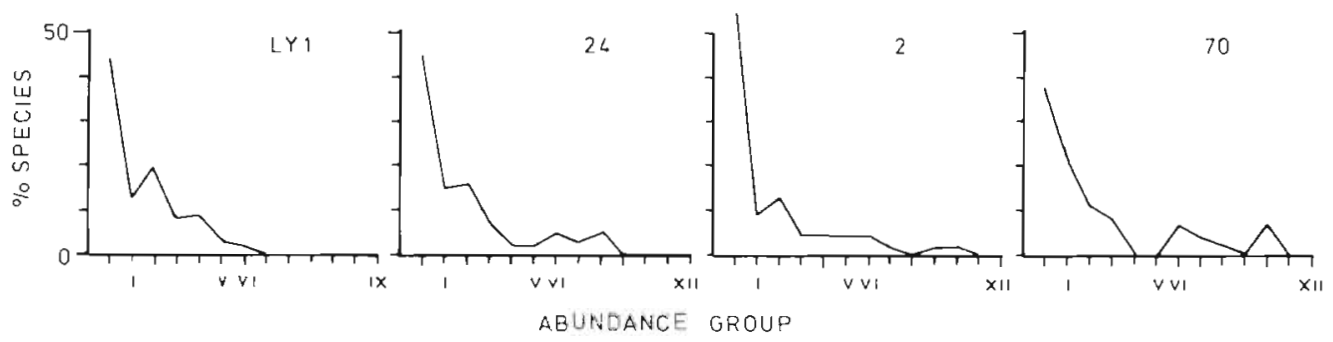

Fig. 1. Log-nornal distribution of individuals among species for 3 stations in Loch Eil $(24,2,70)$ and a control station outside the loch (LY1). In each case the data are from a compilation of 36 grab samples taken over 1 yr (1975-76), expressed as numbers per square metre. Percentage of species in each of the following 12 abundance classes (individuals $\mathrm{m}^{-2}$ ): $0<1$; I 1; II 2-3; III 4-7; IV 8-15; V 16-31; VI 32-63; VII 64-127; VIII 128-255; IX 265-511; X 512-1023; XI 1024-2047; XII 2048-4095

combined faunal data for the year from each station have been plotted as number of species per geometric class against number of individuals per species (Fig. 1). Because of the relatively large sample size many species occurring at low densities were sampled, thus the low abundance classes are well represented in each area. However, there is a progressive reduction in the number of species present in the low abundance classes and an increase in the number present in the higher abundance classes as the relative organic enrichment of the sampled area increases. At the control station, LY1, which is well beyond the Loch Eil system and has a low organic input (Pearson, 1982a), over $95 \%$ of the species occur in the first 5 abundance classes (densities of less than $32 \mathrm{~m}^{-2}$ ) and the highest abundance class represented is Class VI. Station 24 at the head of Loch Eil, which is considered to be moderately enriched by pulp mill effluent, has somewhat fewer species in the first 3 abundance classes but increased numbers in Classes VI to VIII, the highest class represented being Class VIII. The deep basin of Loch Eil receives the greatest input of organic material and of the 2 stations sampled in this area. Station 2 lies on the edge of the basin and is considered to be slightly less enriched than Station 70 in the centre of

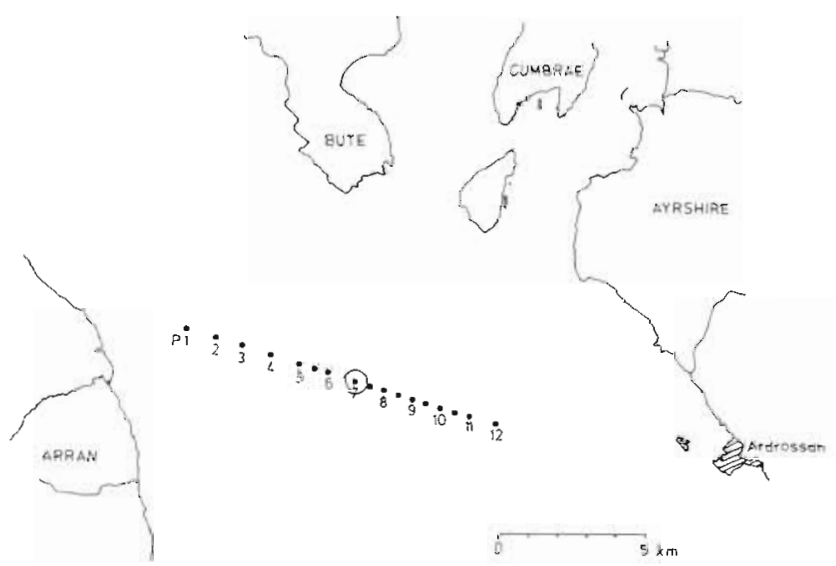

Fig. 2. Position of sampling transect on Garroch Head sewage sludge dumping ground, Firth of Clyde the basin. This is reflected in the abundance distributions. At Station 70 the lower abundance classes are severely curtailed, and the classes above Class $\mathrm{V}$ are enhanced, with the highest class represented being Class X. Moreover, with Classes IV and V being unrepresented the highest classes are entirely divorced from the lower along the distribution axis. The distribution at Station 2 is intermediate between that at Station 24 and Station 70, i. e. there is a progressive increase in the number of species present in the higher abundance classes as organic enrichment of the sediment increases.

In the unpolluted area the highest abundance classes represented are Classes V and VI (16 to 64 individuals). In the more polluted areas these classes are first enhanced at low levels of enrichment (Stations 24 and 2 , partly) and then again reduced as the higher abundance classes increase (Stations 70 and 2, partly). Hence the species group composing these classes is indicative of the changing influence of pollution. Table 1 lists the species present in Classes V and VI in each area, together with the successional phase to which each was assigned along a gradient of organic enrichment in the previous analysis of the influence of pollution on the system (Pearson, 1975). At the control station, LY1, the species present in these classes were previously identified as dominants of the normal community. At Station 24 , subject to moderate pollution, many of the species found in these 2 classes were previously noted as dominants under slightly enriched conditions. Station 2 , considered to be moderately to heavily polluted, has species in these classes which were previously identified as dominants under enriched or heavily polluted conditions. The heavily polluted Station 70 has few species present in these classes, but of the 3 in Class VI, 2 were identified previously as dominant under polluted conditions.

It appears therefore that at Stations 24 and 2, the 6 species constituting these 2 geometric abundance classes are representative of slight and moderately heavy pollution. The only species common to the 2 classes is Glycera alba, which was formerly identified as a 
dominant of the nonnal community. This carnivorous polychaete has been the subject of intensive investigation (Blackstock, $1980 \mathrm{a}, \mathrm{b}$ ), because of its ability to survive a wide range of conditions along a gradient of organic enrichment.

\section{GARROCH HEAD SLUDGE DUMPING GROUND, FIRTH OF CLYDE, SCOTLAND}

In 1979 and 1980 detailed surveys were made of the benthic fauna of an area of the Firth of Clyde, subjected to the regular deposition of sewage sludge. Preliminary results from these surveys have been reported by Pearson (1982c) and a full account will be given elsewhere. A $10 \mathrm{~km}$ long transect of sampling stations was occupied, which extended over the centre of the dumping grounds (Fig. 2). Single grab samples were obtained at $1 \mathrm{~km}$ intervals along the outer end of this transect and at $0.5 \mathrm{~km}$ intervals within $3 \mathrm{~km}$ of the centre of the dumping grounds. The benthic fauna along this transect varied in a characteristic way best illustrated by a consideration of SAB statistics as exemplified in Pearson and Rosenberg (1978) (Fig. 3). The number of species (S) found was low in the centre of the dumping grounds, rose to a peak some $2 \mathrm{~km}$ from the centre and then declined towards the end of the transect. Biomass (B) was greatest in the centre of the grounds $;$ it declined to the outer edge of the grounds before reaching a secondary peak between 1 to $2 \mathrm{~km}$ from the centre and then declined towards the outer ends of the transect. Abundance (A) rose steadily to reach a peak in the centre of the grounds. These changes are caused by the dominance of dense populations of a few small opportunistic annelid species in the centre of the grounds. These are successively replaced by smaller numbers of an increasing variety of larger species as distance from the centre increases. The secondary biomass peak is associated with the mixed populations in the moderately polluted areas around the centre of the grounds (see Pearson and Rosenberg, 1978, for a detailed consideration of the phenomenon). The faunal changes are closely associated with changes in the chemistry of the sediments brought about by the deposition of the sewage sludge. These effects are indicated by the change in redox potential values in the sediments, shown in Fig. 3, from positive values at the unpolluted ends of the transect to highly negative values in the centre of the grounds.

An analysis of the faunal data from this transect by number of species per geometric class reveals a characteristic pattern to the distribution of such groups along the transect (Fig. 4). It must be noted that the data are based on a single $0.1 \mathrm{~m}^{2}$ grab sample taken at each point on the transect, and that the abundance numbers have been raised to numbers per $\mathrm{m}^{2}(\times 10)$ in order to maintain comparability with data from other areas. This necessitates the amalgamation of the first 4 geometric scale units and undoubtedly distorts the lower end of the abundance scale. Experience has shown that a single grab sample from this ground recovers about $30 \%$ of the total species present; however, rarer species are not collected when sampling is restricted, and the general trends along the transect are for a steady increase in the higher abundance classes as distance from the centre of the dumping ground diminishes. This data set therefore does not fulfil the basic requirements of the method in that the sample size is too small and the species number is far from exposing the mode of log-normal distribution. Yet the set illustrates the robustness of the method in applying it to a small sample size. Fig. 4 shows that

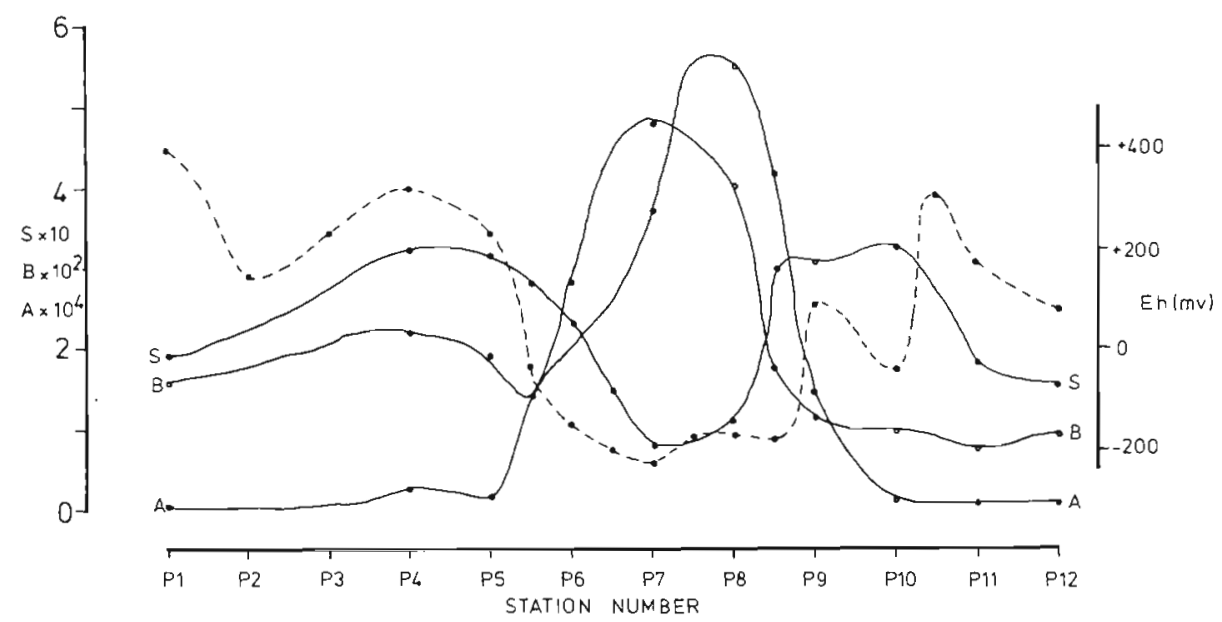

Fig. 3. Faunal variation along east-west transect over Garroch Head ground. S number of species; $A$ total abundance $\left(\text { No. } m^{-2}\right)_{i} B$ wet weight biomass $\left(\mathrm{g} \mathrm{m}^{-2}\right)$; P1-P12 sampling stations along tansect. Broken line: Change in redox potential at $40 \mathrm{~mm}$ depth in sediment $(\mathrm{Eh}, \mathrm{mV})$ 


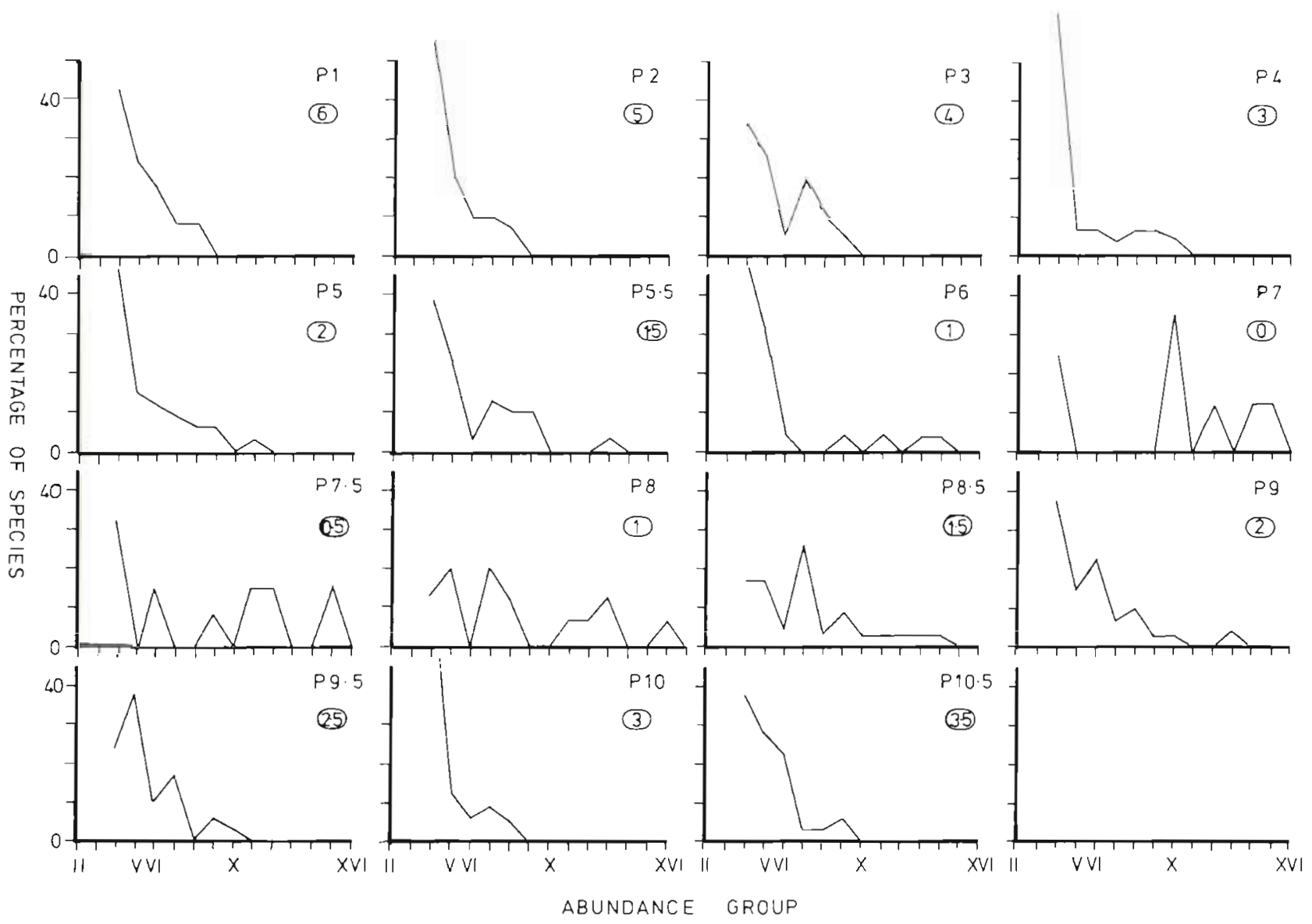

Fig. 4. Distribution of individuals among species for stations along the east-west transect over the Garroch Head ground. Distance $(\mathrm{km})$ from centre of dumping ground (encircled number) given in each case. Scales as for Fig. 1

Stations $\mathrm{P} 1$ and $\mathrm{P} 2$ at 6 and $5 \mathrm{~km}$ from the centre have species concentrated in the lower abundance classes with no species occurring in a class higher than VIII, i. e. plots typical of unpolluted areas. From Station 3 inwards the number of species in the higher abundance classes increases progressively; the number of individuals in the lower classes diminish until at the stations in the centre of the grounds, where there is a constant input of sludge to the sediments (Stations P7, 7.5 and 8), the majority of species are found in the higher abundance groups and very few low-abundance species are present. The plots from these polluted stations form groups of binomial distributions instead of the smooth curves of Stations P1 and P2. A similar trend is followed along the eastern arm of the transect with a gradual increase in the lower abundance classes as distance from the centre increases.

The group of species constituting the middle range of abundance classes (i. e. Class V [16 to 31] and Class VI [32 to 63]) from those areas along the transect where changes in the distribution of abundances along the geometric scale are first noted (Stations $3,4,5,9.5,10$ ) are listed in Table 2. It might be expected that these classes would contain those species that have shown the greatest sensitivity to the environmental change in that they are increasing in numbers and beginning to move up the abundance scale. This is confirmed by the change in abundance of such species along the pollution gradient (Fig. 5). The pattern found in all species noted is that of low numbers at the outer, western end of the transect more than $5 \mathrm{~km}$ from the centre of the dumping grounds. Numbers rise gradually to a high level between 2 to $4 \mathrm{~km}$ from the centre before declining rapidly in the central highly polluted areas. These are therefore members of that intermediate group of species which exhibits a population increase under low levels of organic pollution and are later eliminated as enrichment increases. The list also includes 1 or 2 species that are dominant in the normal population but decline rapidly as pollution increases (e. g. Aphrodita aculeata, Terebellides stroemi), and one of the opportunists that become extremely abundant under highly polluted conditions (Capitella capitata). However, in general the list contains species whose populations initially expand under moderate levels of organic enrichment. 
Fig. 5. Change in abundance of species listed in Table 2 along Garroch Head transect

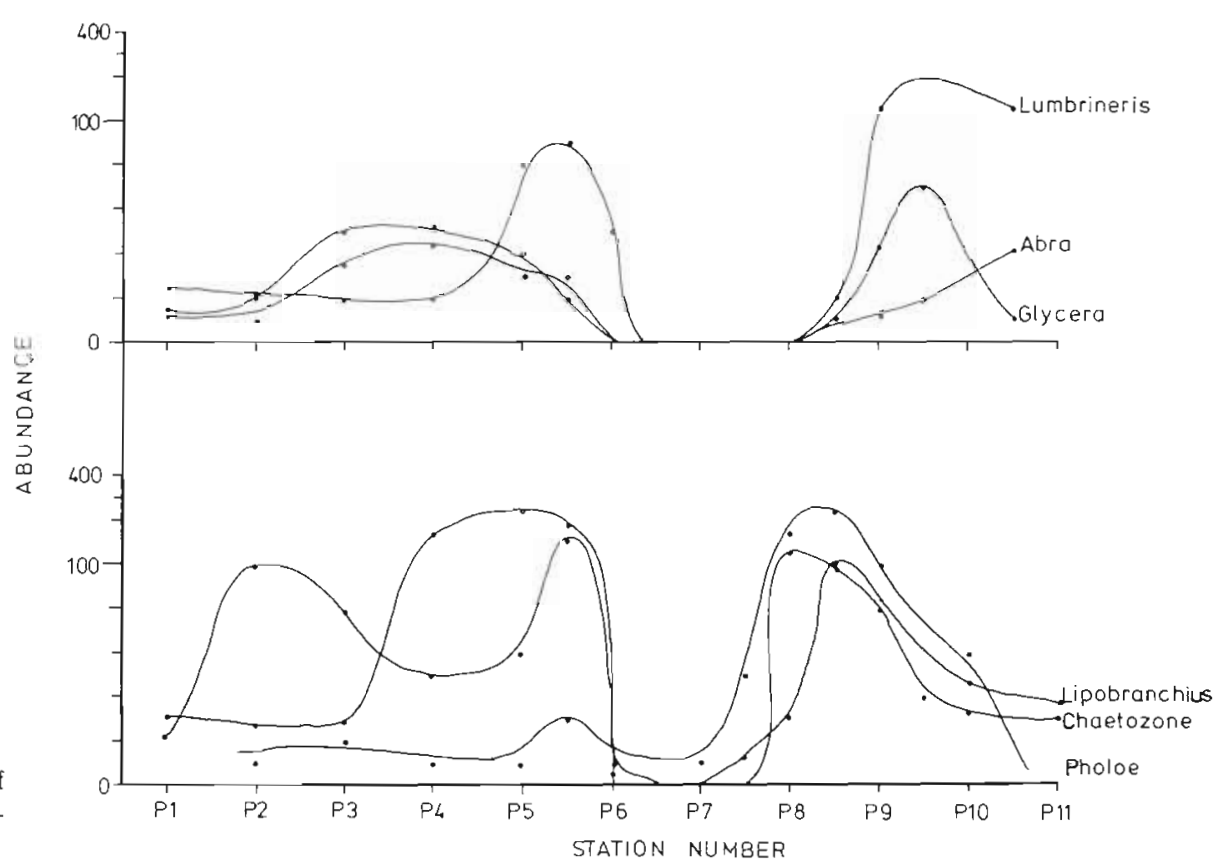

\section{FJORDS IN THE BERGEN DISTRICT, NORWAY}

In 1979 and 1980 extensive surveys were made of the macrobenthic fauna of various fjord areas in the vicinity of Bergen subject to actual or potential pollution. A preliminary report of these surveys has been given by Johannessen (1981) and the detailed results will be reported elsewhere. The areas sampled are shown in Fig. 6. Sewage from the highly polluted Nordåsvannet has recently been transferred through 2 tunnel systems and discharged into areas close to Stations 24 and 25. The Nordåsvannet remains seriously affected, however, with greatly enriched sediments. The inner basin where water circulation is severely restricted by sills between Stations 18 and $19 a$, continues to be the area most affected by effluent. The area beyond the Grimstadfjord, known as Raunefjord, is as yet little influenced by the new discharges. This is apparent from Fig. 7 which shows the percentage weight loss on ignition and the calcium carbonate content of the sediments at the various sampling stations. These indirect measures of the carbon content of the sediments demonstrate an increasing gradient of enrichment from the Raunefjord to the Nordåsvannet stations, i. e. in order of decreasing distance from the original pollutant source, with Station 19a in the land-locked basin of Nordassvannet being the most affected. The increasing effect of pollutant inputs can be inferred from the distribution of species per geometric abundance class (Fig. 8) for samples from the area taken in October 1980. At Station 8 the majority of the species occur in the first 4 abundance classes and there is a rapid decline in the numbers present in the higher abundance classes. This situation is gradually reversed through Stations 25, 7, 24 and 18 with proportionately fewer species in the lower abundance classes and more in the higher abundance classes until, at Station 19a, the species are spread more or less evenly through a greatly extended range of geometric abundance classes. Thus the stations occupying an intermediate posi-

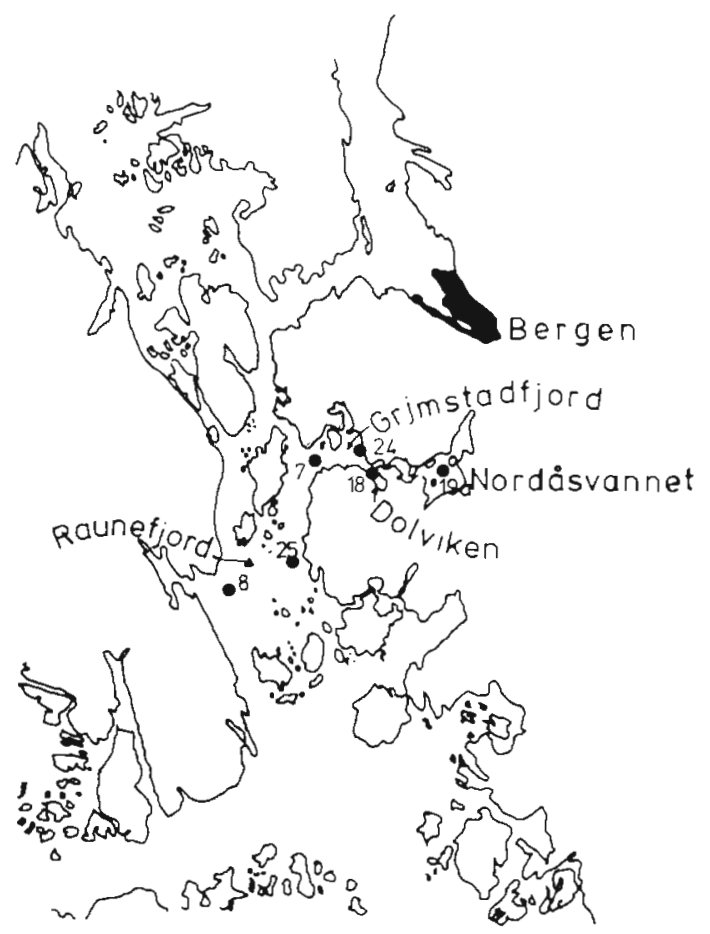

Fig. 6. Survey areas near Bergen showing sampling stations 


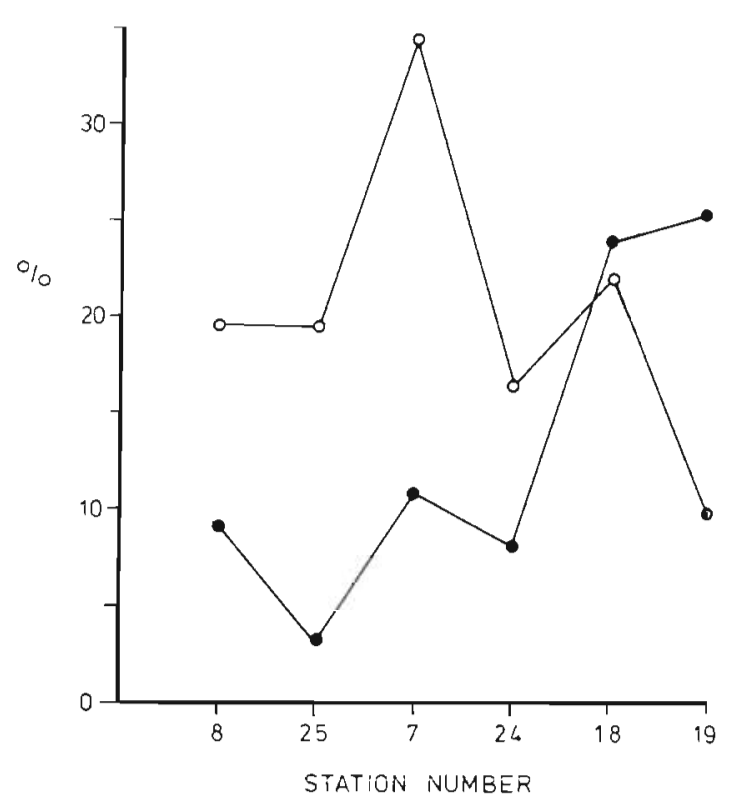

Fig. 7. Percentage weight loss on ignition (filled circles) and percentage calcium carbonate content (open circles) of sediments at various sampling stations near Bergen

tion along the gradient of organic enrichment in this area are Stations 25,7 and 24 . It might be expected that the fauna in these areas would contain those species demonstrating increased or decreased sensitivity to the environmental change by way of changing population densities. Table 3 lists the species present in geometric abundance Classes V and VI at these 3 stations. Most of the species are present in low numbers if at all in the unpolluted area at Station 8 , but their populations increase along the gradient of increasing pollution before declining rapidly in the areas of greatest input at Stations 18 and 19a.

This is clearly seen in Fig. 9a, b and $\mathrm{c}$ which summarizes the abundance changes of a number of these species at the 6 stations mentioned, ordered along a gradient of increasing pollution effect. Thus among the molluscs the various Thyasira species reach peak abundances at different distances from the pollutant source and then decline. Species of Yoldiella and Parvicardium behave similarly as does the Ophiurid Amphiura and the polychaetes Glycera, Pholoe, Diplocirrus and Melinna. Table 3 does, however, list species that exhibit no apparent population change prior to declining at the inner end of the gradient. Such species are exemplified in Fig. 9a by the polychaete Myriochele occulata which maintains a relatively high and constant population over all but the inner end of the gradient. Species which achieve very large populations in the highly polluted areas are not well represented in the list. They are not present at the outer low input end of the gradient and occur only in low numbers, if at all, in the central part, but these populations increase very rapidly in the latter part of the gradient. This pattern is seen in the polychaete Anaitides groenlandica (Fig. 9b). However despite these exceptions the majority of the species listed in Table 3 were those whose populations first increase and later diminish along a gradient of increasing pollution.
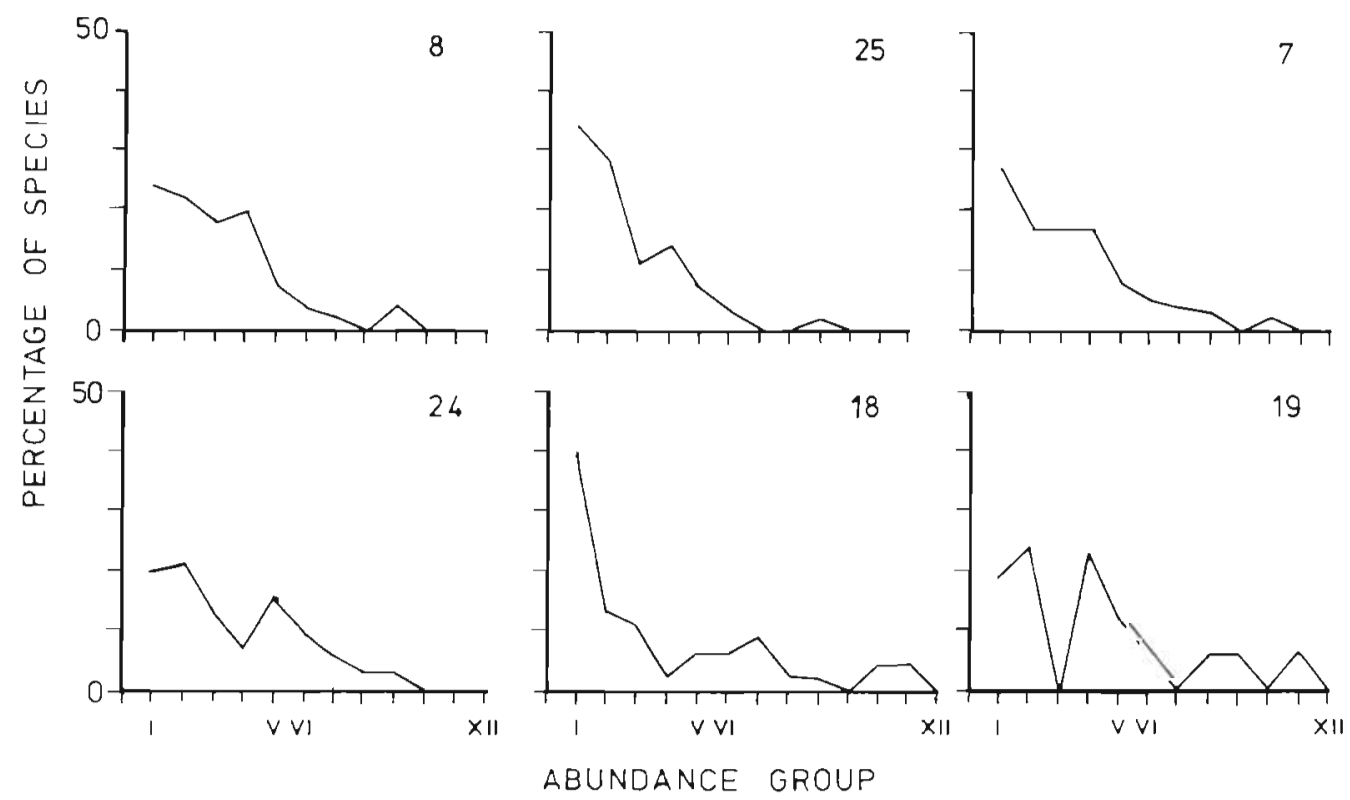

Fig. 8. Distribution of individuals among species for stations in the Bergen area, October 1980. Scales as for Fig. 1 

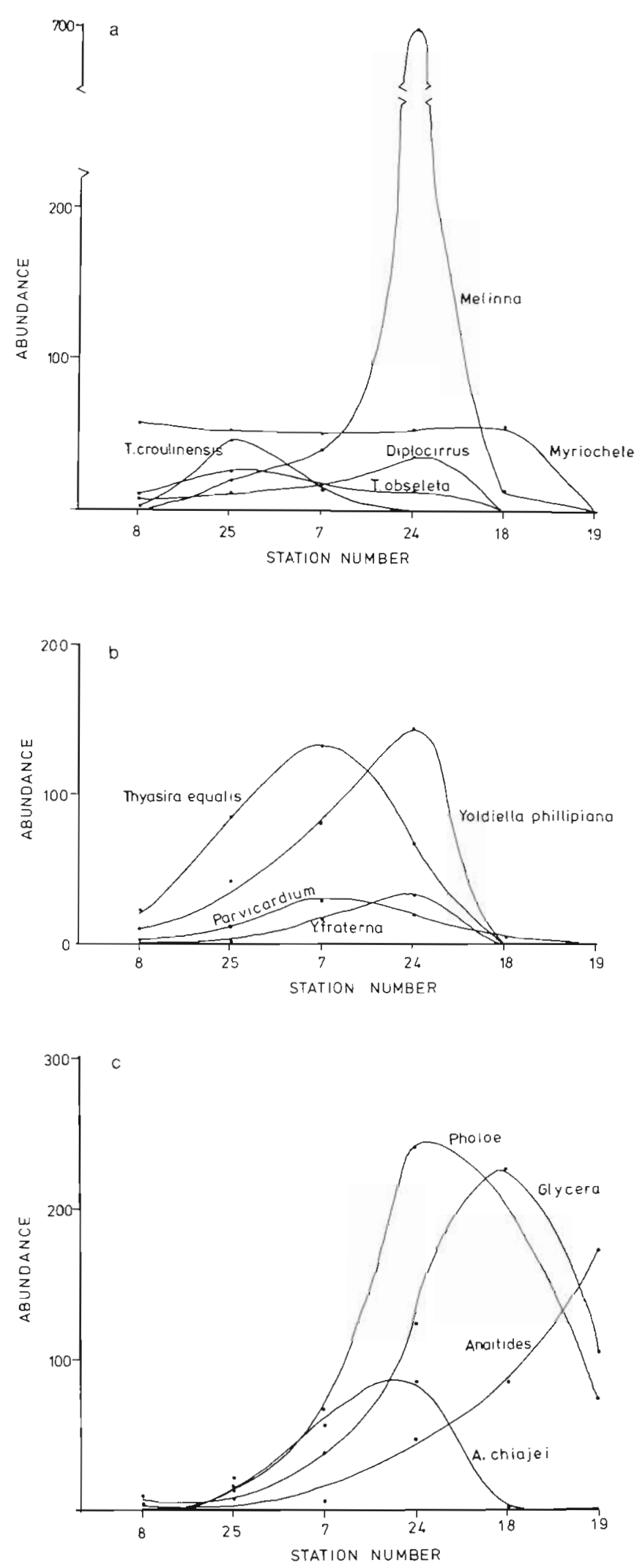

Fig. 9a-c. Change in abundance of species listed in Table 3 from stations in Bergen area, ordered along a gradient of increasing pollution
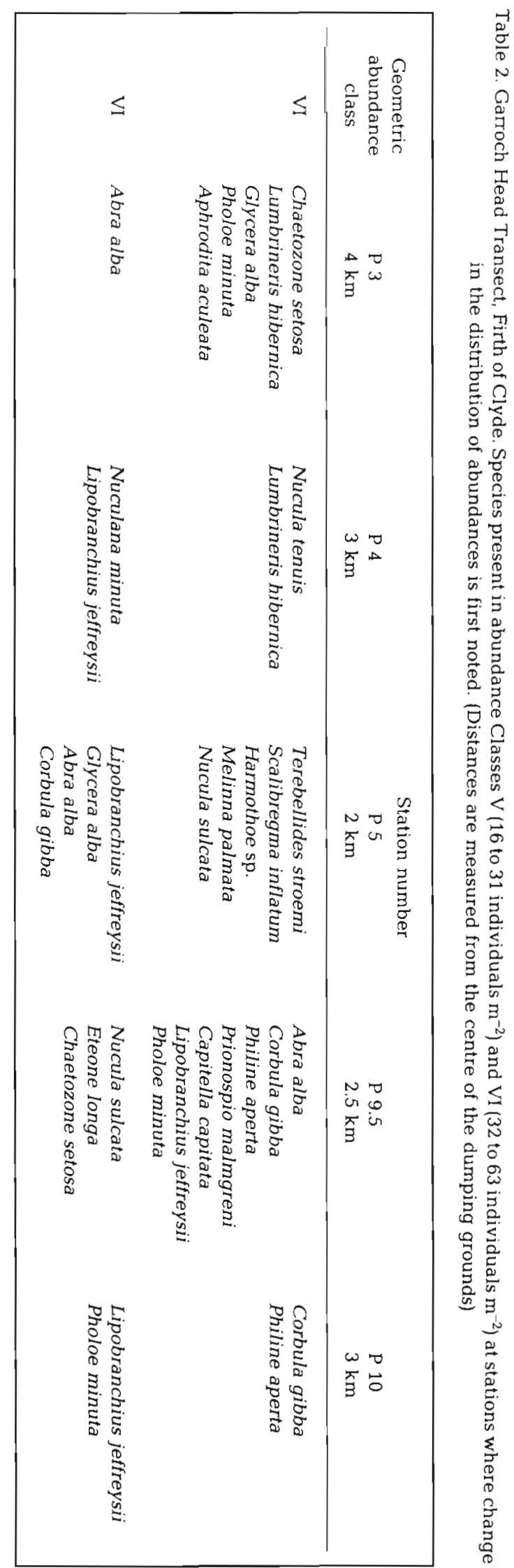
Table 3. Grimstadfjord, Bergen. Species present in abundance Classes V and VI at stations in the centre of the gradient of organic pollution

\begin{tabular}{|c|c|c|c|}
\hline $\begin{array}{c}\text { Geometric } \\
\text { abundance } \\
\text { class }\end{array}$ & 25 & Station number & 24 \\
\hline $\mathrm{V}$ & $\begin{array}{l}\text { Amphiura chiajei } \\
\text { Thyasira obsoleta } \\
\text { Venus striatula } \\
\text { Lepidopleurus asellus } \\
\text { Onchnesoma steenstrupi } \\
\text { Eclysippe vanelli } \\
\text { Heteromastus filiformis } \\
\text { Owenia fusiformis } \\
\text { Pholoe minuta } \\
\text { Anaitides groenlandica } \\
\text { Melinna cristata }\end{array}$ & $\begin{array}{l}\text { Amphiura chiajei } \\
\text { Abra nitida } \\
\text { Parvicardium minimum } \\
\text { Kelliella miliaris } \\
\text { Myrtea spinifera } \\
\text { Thyasira pygmaea } \\
\text { Thyasira croulinensis } \\
\text { Lima subauriculata } \\
\text { Yoldiella fraterna } \\
\text { Yoldiella philippiana } \\
\text { Nucula tumidula }\end{array}$ & $\begin{array}{l}\text { Ampharete finmarchica } \\
\text { Anaitides groenlandica } \\
\text { Eteone longa } \\
\text { Goniada maculata } \\
\text { Scoloplos armiger } \\
\text { Tharyx marioni }\end{array}$ \\
\hline $\mathrm{VI}$ & $\begin{array}{l}\text { Thyasira croulinensis } \\
\text { Parvicardium minimum } \\
\text { Siphonodentalium lofotense } \\
\text { Myriochele occulata } \\
\text { Aricidea jeffreysii } \\
\text { Trochochaeta multisetosum }\end{array}$ & $\begin{array}{l}\text { Glycera alba } \\
\text { Chaetozone setosa } \\
\text { Ophelina cylindricaudata } \\
\text { Praxillella sp. } \\
\text { Melinna cristata }\end{array}$ & $\begin{array}{l}\text { Thyasira equalis } \\
\text { Parvicardium minimum } \\
\text { Nuculana minuta } \\
\text { Yoldiella fraterna } \\
\text { Notomastus latericeus } \\
\text { Myriochele occulata } \\
\text { Streblosoma bairdi } \\
\text { Diplocimus glaucus }\end{array}$ \\
\hline
\end{tabular}

\section{THE EKOFISK AREA, NORTH SEA}

A detailed survey of the benthic macrofauna around oil platform installations in the Ekofisk area of the North Sea was carried out by Dicks (1976). Sampling stations were located along a series of 5 radiating transect lines centred on the oil installations and extending $6 \mathrm{~km}$ in each direction (Fig. 10). The survey was carried out in 1973, several years after the initial development of the Ekofisk oil field and following the installation of the central production complex, from the area of which the transect lines radiated. The survey was designed with the intention of assessing the possible effect of the drilling and construction activity of the previous few years on the benthic populations of the area and to provide baseline information against which future changes might be assessed. Conventional analysis of the survey information, based on the fauna from a total of 10 replicate samples at each station, included the calculation of 3 differing diversity indices (Shannon-Wiener, Gleason \& Menhinick) and a subjective assessment of species dominance over the area.

It was concluded that the distribution of organisms was relatively uniform throughout the area and that there was no evidence of ecological damage to the benthos associated with the existing oil installations (Dicks, 1976). An exhaustive list of the faunal data obtained at each sampling station is included in the published report and it is possible to reanalyse the data by the method being considered here.
Fig. 11 shows that at sites $6 \mathrm{~km}$ from the installation, the distribution is clearly log-normal rather than a log series (here a high number of samples was taken and the mode is exposed), yet the data reveal groups of species ( 3 at $N$. and S. E., and 4 at N. E. and S. W.

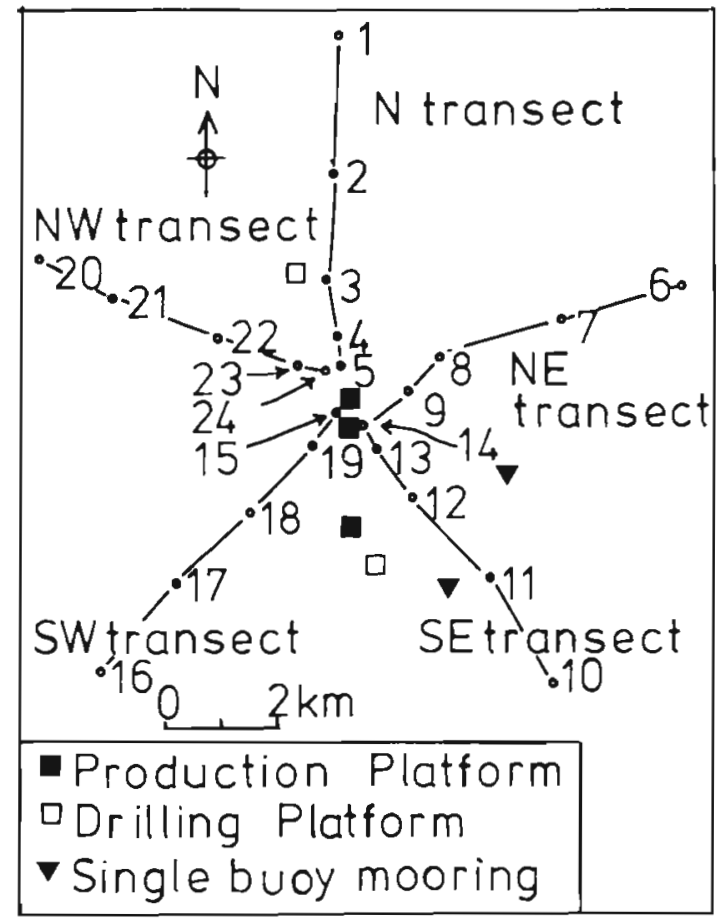

Fig. 10. Ekofisk oil field area, North Sea, showing sampling transects. (After Dicks, 1976) 


\section{DISTANCE FROM PRODUCTION COMPIEXX}

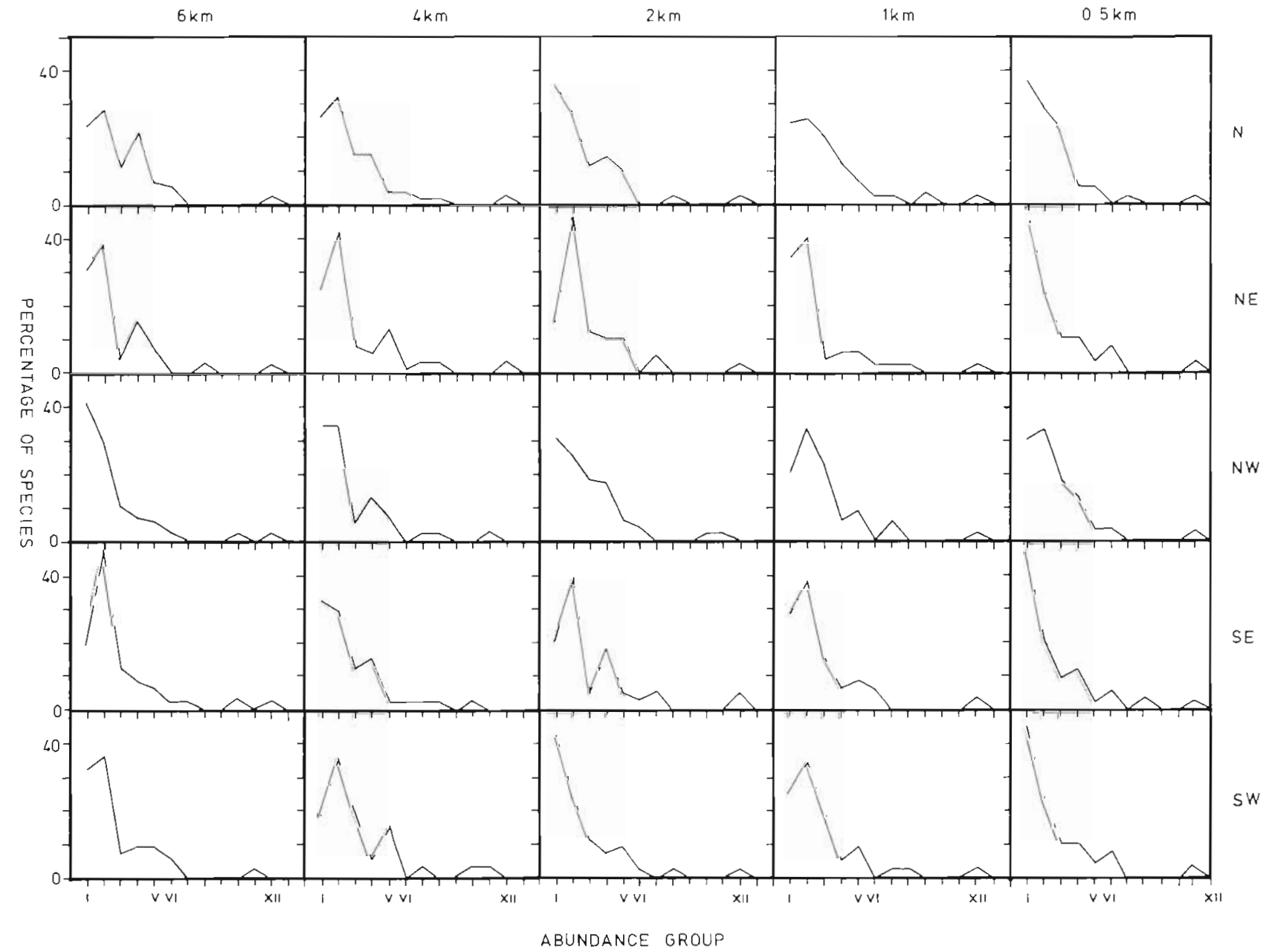

Fig. 11. Distribution of individuals among species for stations in the Ekofisk area. Stations are positioned at equivalent distances along each of 5 radiating transects. Scales as for Fig. 1

transects). The N.W. transect shows a smooth lognormal pattern, with a clear mode. For all transects the trend from the $6-\mathrm{km}$ stations towards the installation is for the groups of species to become more distinct (particularly in the N.W. transect) and to move along the abscissa towards higher abundance classes. The trends are present, therefore, as in the other data sets but they are slight and there is no clear evidence of dramatic effects of pollution. At all stations one species, Myriochele heeri, was present in high abundances in all samples (Class XI or XII) and its dominant ubiquity may be discounted for the purposes of comparison. On the assumption that the existence of any gradient of faunal change will be reflected in the populations of individual species it is apposite now to examine those species which make up the middle abundance classes ( $\mathrm{V}$ and VI) at stations where a gradient of change is first suspected. Table 4 lists such species from stations along the North transects.
The changes in abundance of the species thus identified are shown in Fig. 12. As might be expected from the relatively uniform nature of the data over the area the changes are small, nevertheless they appear to show a discernible and explicable pattern. A majority of the species have low numbers at the station closest to the installations and relatively high populations at the station $0.5 \mathrm{~km}$ further out. Lower populations are found again at the station $2 \mathrm{~km}$ from the installations before stabilizing at somewhat higher populations 4 to $6 \mathrm{~km}$ from the installations. This pattern is seen in the ophiuroid Amphiura filiformis and the polychaetes Owenia fusiformis, Nephtys incisa and Scoloplos armiger. The populations of the predatory polychaetes Goniada maculata and Glycera alba appear to change in an inverse manner along the transect. They are both present in similarly low numbers close to the installations, but between 1 and $2 \mathrm{~km}$ G. maculata predominates, whereas at the outer stations $G$. alba is more 


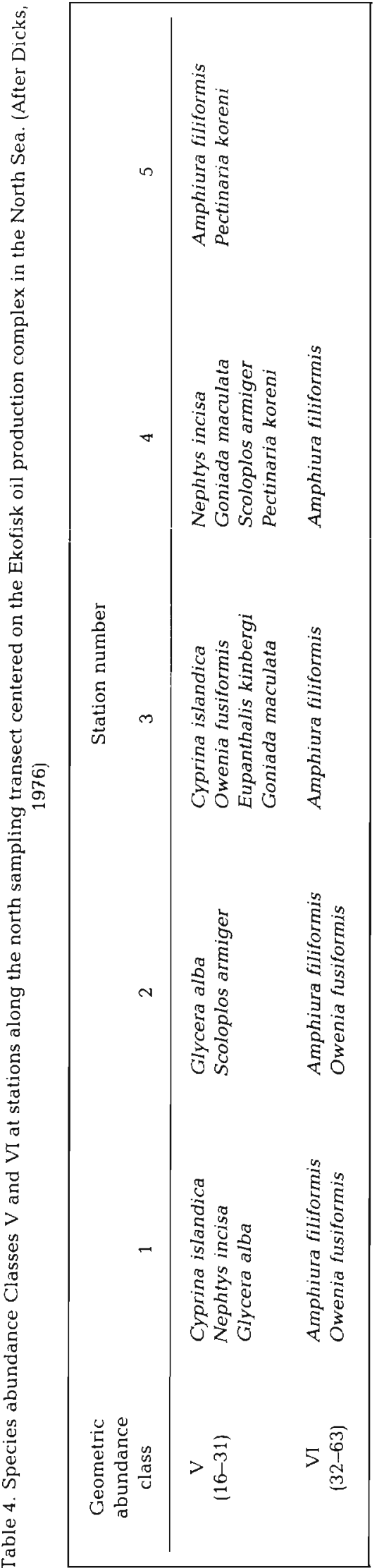

numerous. The polychaete Pectinaria koreni has its largest populations closest to the installations; its numbers decline steadily along the transect with increasing distance from the centre. It seems therefore that all the species identified in Table 4 exhibit noticeable population changes along a gradient outwards from the oil installation complex. The changes are small and might not be remarkable if each species were considered in isolation. Taken as a whole they appear to indicate a disturbance to the benthic communities centred on the installations. A similar slight disturbance appears to be evident along the length of the 2 southerly transects. One possible explanation of this is that the prevailing pattern of water movement in the area is from $N$ to $S$ (Dicks, 1976), thus the sediments to the south of the area of drilling and construction activity might be expected to be subjected to a greater loading of effluent and particulate material from the complex.

\section{MILFORD HAVEN, WALES}

A survey of the sublittoral macrofauna of Milford Haven, an extensive inlet on the S. W. coast of Wales and the site of a major oil terminal, was described by Addy (1976). A series of stations throughout the Haven were sampled using a $0.1 \mathrm{~m}^{2}$ grab with either 5 or 10 replicates being taken at each site. A large variety of substrates and conditions are found within the area, ranging from fully marine semi-exposed areas in the outer western parts to estuarine, sheltered inner reaches. Data from 2 areas in the Haven have been used for comparison: (1) a series of 4 stations along a transect in Angle Bay, a semi-enclosed sheltered embayment in the central part of the Haven; (2) a series of 6 stations on a transect in the inner part of the Haven from the estuarine area at Pembroke Dock to a station opposite Popton Point $6 \mathrm{~km}$ further down the Haven (Fig. 13). Faunal data are presented in the original report as a full list of species abundances, thus an analysis of the distribution of species among abundance classes can be undertaken.

\section{Angle Bay}

The percentage distribution of species among geometrically scaled abundance classes is shown in Fig. 14 for the 4 stations along the Angle Bay transect. The data are based on 10 samples at each station. It is immediately apparent from the distribution of species among abundance classes along the axis that the communities along the transect do not follow the usual pattern; all show typically disturbed patterns with 2 or 3 clearly distinct groups of species rather than a 
Fig. 12. Change in abundance of species listed in Table 4 along north transect in the Ekofisk field
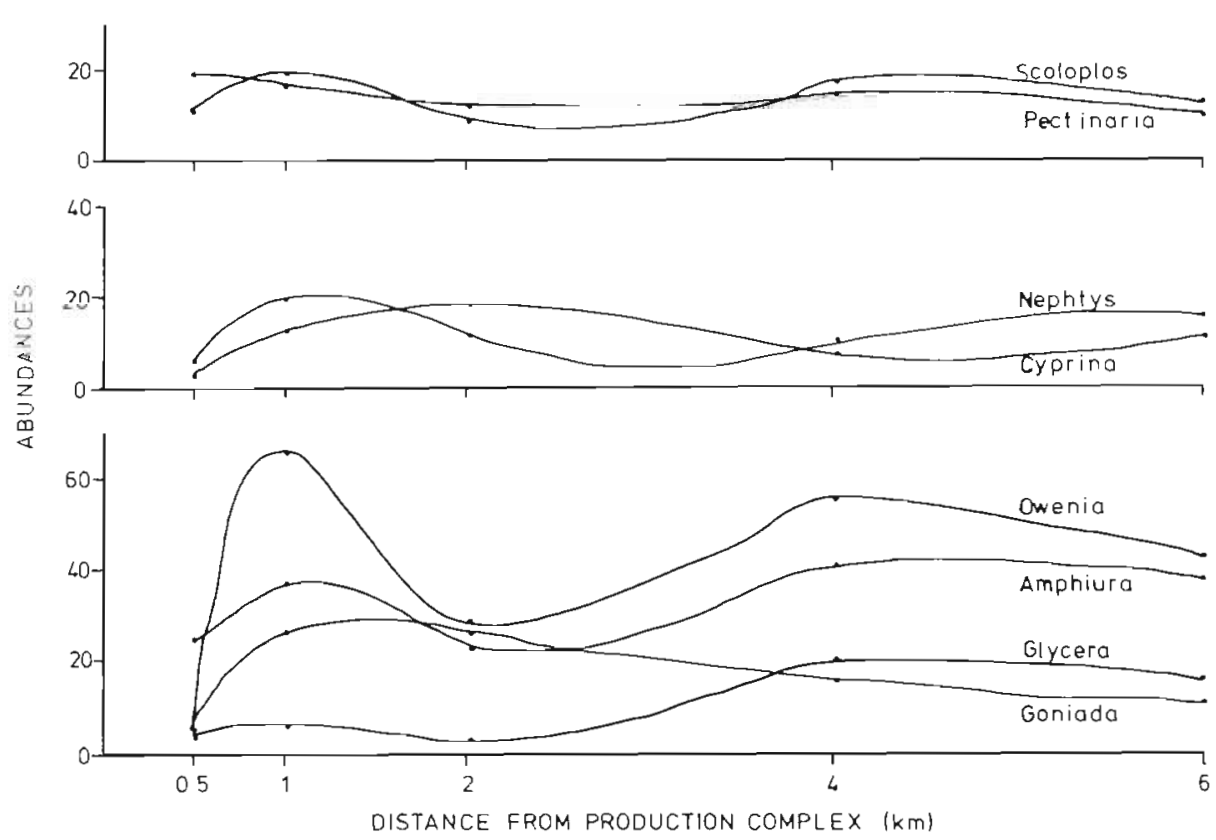

smooth curve. Despite this irregularity at each of the stations, it is possible to discern a trend from the inshore (15) to the offshore (18) station. At the inshore station abundance Classes III and IV are unrepresented and Classes V and VI are well represented. As distance from the shore increases, Classes $V$ and VI show an irregular pattern but with a slight tendency to decrease from Stations 15 to 18 , whereas Classes III and IV increase. The overall effect is a redistribution of abundances towards the higher classes. The species occurring in abundance Classes $V$ and VI along the transect are listed in Table 5 . Only 8 species make up these classes at the 4 stations; their relative abundance changes along the transect are shown in Fig. 15a and b. Let us consider first the 3 species found in Class $V$ at the innermost station. These all attain much larger populations at the outer end of the transect. Moreover, of the 5 species in Class VI at Station 15, Clymene oerstedi and Lumbrineris sp. increase markedly in numbers at the later stations, whereas Lanice conchilega and Eulalia sanguinea decline. Only one of the species listed, Thyasira flexuosa, maintains relatively stable populations along the transect. Thus if the tran- sect is regarded as representing a gradient of population change from inshore to offshore then species indicative of both positive and negative change were defined in abundance Classes V and VI at the innermost station.

\section{Pembroke Dock to Popton Point}

The percentage distribution of species among geometric abundance classes at the 6 stations along this transect is shown in Fig. 16. Again, a very irregular distribution is found at all the stations, typical of a

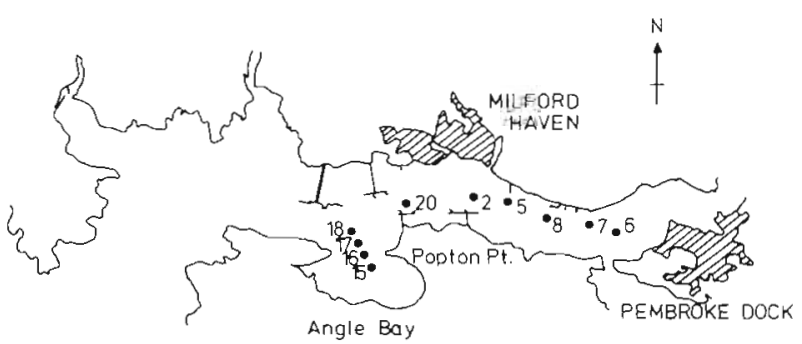

Fig. 13. Milford Haven area showing the sampling stations used. (After Addy, 1976)

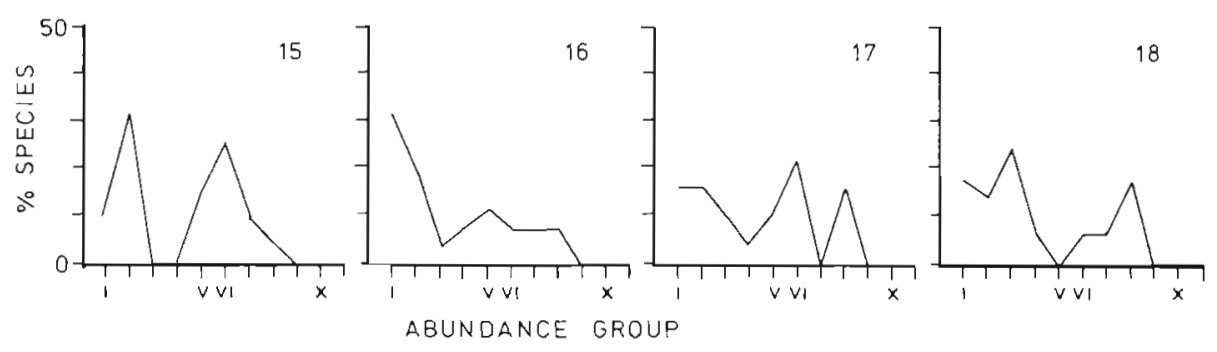

Fig. 14. Distribution of individuals among species for stations on Angle Bay transect, Milford Haven. Scales as for Fig. 1 
Table 5. Angle Bay, Milford Haven. Species in abundance Classes V and VI at stations along a transect from inshore (15) to the centre of the bay (18). (After Addy, 1976)

\begin{tabular}{|c|c|c|c|c|}
\hline \multirow{2}{*}{$\begin{array}{l}\text { Geometric } \\
\text { abundance } \\
\text { class }\end{array}$} & \multicolumn{4}{|c|}{ Station number } \\
\hline & 15 & 16 & 17 & 18 \\
\hline $\begin{array}{c}V \\
(16-31)\end{array}$ & $\begin{array}{l}\text { Notomastus latericeus } \\
\text { Melinna palmata } \\
\text { Abra alba }\end{array}$ & $\begin{array}{l}\text { Notomastus latericeus } \\
\text { Melinna palmata } \\
\text { Tellina fabula }\end{array}$ & $\begin{array}{l}\text { Notomastus latericeus } \\
\text { Tellina fabula }\end{array}$ & \\
\hline $\begin{array}{c}\text { VI } \\
(32-63)\end{array}$ & $\begin{array}{l}\text { Lumbrineris sp. } \\
\text { Eulalia sanguinea } \\
\text { Clymene oerstedi } \\
\text { Lanice conchilega } \\
\text { Thyasira flexuosa }\end{array}$ & $\begin{array}{l}\text { Lumbrineris sp. } \\
\text { Scoloplos armiger }\end{array}$ & $\begin{array}{l}\text { Lumbrineris sp. } \\
\text { Scoloplos anmiger } \\
\text { Melinna palmata } \\
\text { Thyasira flexuosa }\end{array}$ & $\begin{array}{l}\text { Thyasira flexuosa } \\
\text { Abra alba }\end{array}$ \\
\hline
\end{tabular}

disturbed community implying considerable fluctuation in community structure in the area. At the innermost station (6), opposite Pembroke Docks, the community is very impoverished consisting of only a few species concentrated in the low abundance classes. At the 3 successive stations downstream of this point the percentage of species in the higher abundance classes increases markedly, but in a very uneven manner. At Station 2-4 km downstream of Station 6 - the community is again impoverished and only low abundance classes are represented; $1 \mathrm{~km}$ beyond this at Station 20 . a more normal distribution is found with both low and intermediate abundance classes being well represented. A station-to-station comparison of abundance distributions therefore suggests a complex faunal situation along the transect responding to more than a simple stress gradient.

Consideration of the species present in the intermediate abundance Classes V and VI tends to confirm this conclusion (Table 6). Because of the faunal impoverishment along the transect not many species are represented, however, examination of the abundance changes of a number of these species along the transect (Fig. 17) shows that they provide a good indication of the changes discussed above. The polychaetes Nephtys sp., Notomastus latericeus and Lumbrineris $\mathrm{sp}$. are represented together with the mollusc Nucula nucleus, and all exhibit a similar pattern. Thus all but Nephtys sp. are absent from the innermost station but have relatively high populations at the next 3 stations. All are markedly reduced at Station 2, but recover again at Station 20. Their individual population fluctuations tend to reflect, therefore, the overall pattern of change in the communities.

\section{MEVAGISSEY BAY, ENGLAND}

Micaceous residue, a slurry of fine-grained inorganic waste from the china clay industry, was for many years discharged into Mevagissey Bay in Cornwall on the S. W. coast of England. Discharge of the waste was reduced in 1970 and finally ceased in 1972 . Various surveys have been carried out to assess the effects of the wastes on the benthic communities of the bay (Howell and Shelton, 1970; Portmann, 1970; Probert, 1975, 1981). In the latter paper, Probert provides time series data on population changes at a station in the
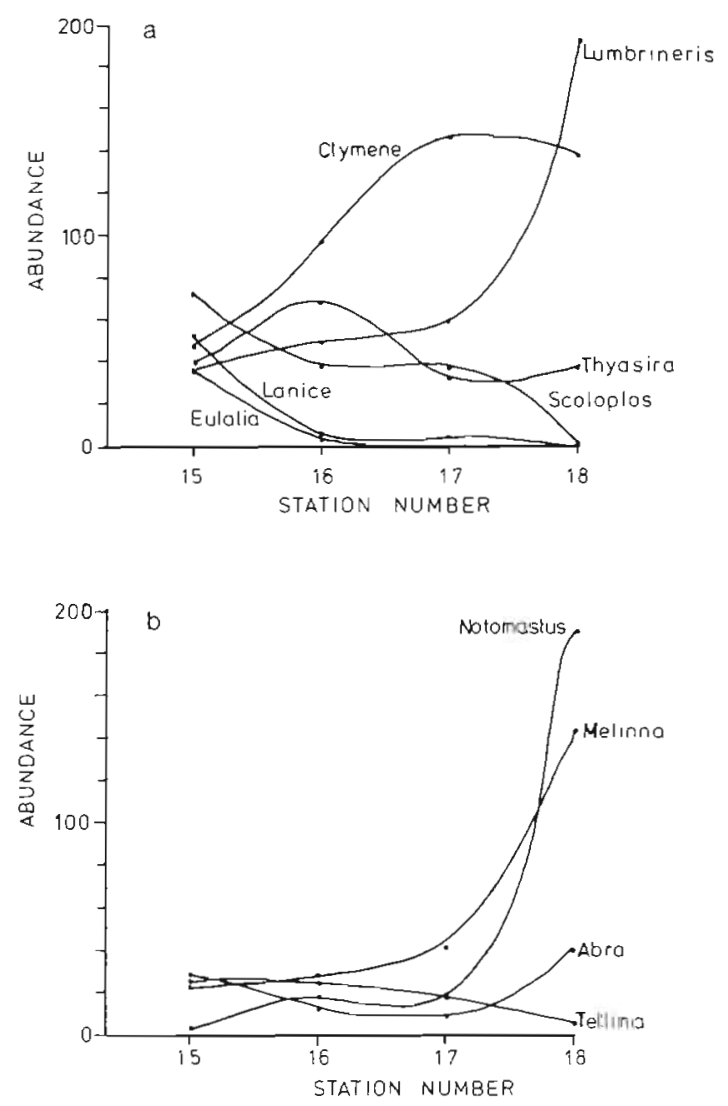

Fig. $15 \mathrm{a}, \mathrm{b}$. Change in abundance of species listed in Table 5 along Angle Bay transect, Milford Haven 
Fig. 16. Distribution of individuals among species for stations along a transect in the inner part of Milford Haven. Scales as for Fig. 1

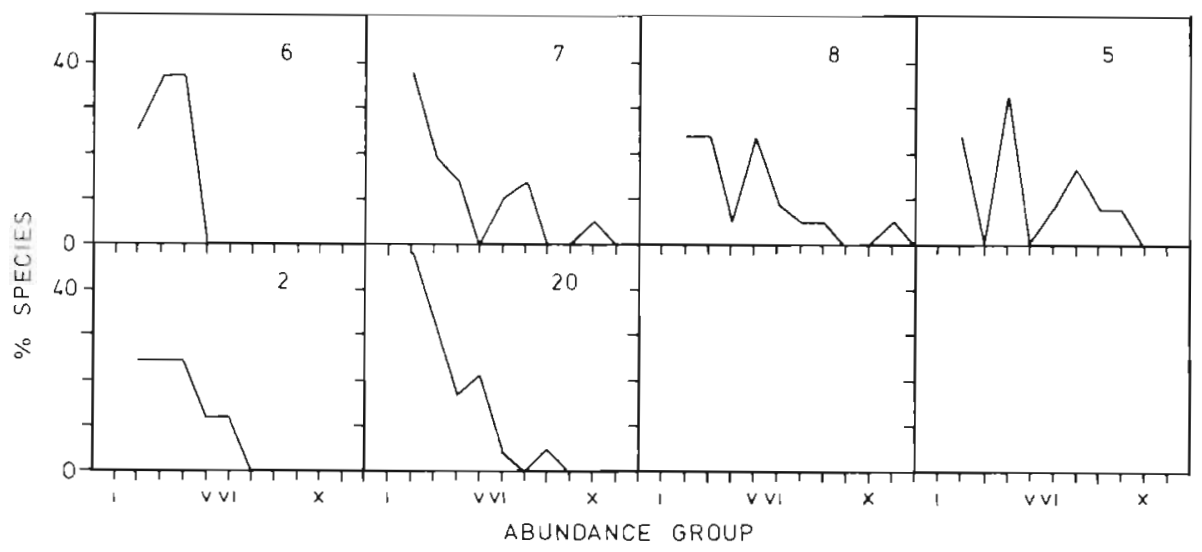

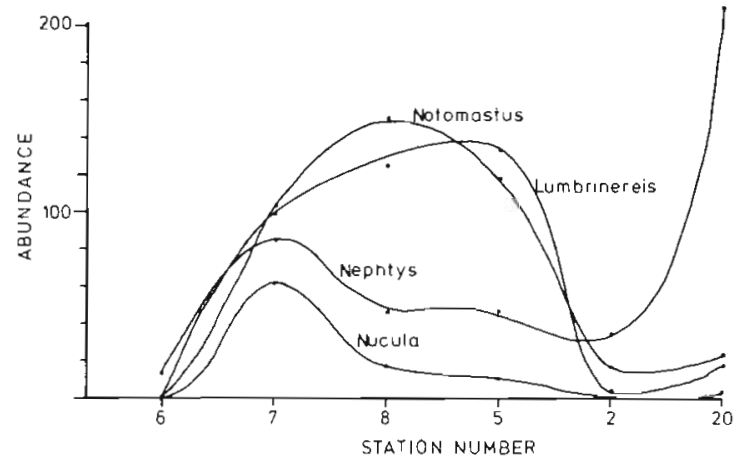

Fig. 17. Change in abundance of species listed in Table 6 along transect from Pembroke Dock to Popton Point, Milford Haven

bay (Station A, $13 \mathrm{~m}$ depth) over a 25 mo period in 1970-72, following a reduction in waste discharge from 700,000 to to 350,000 tons $\mathrm{yr}^{-1}$. From an examination of population trends among the numerically dominant species and the Margalef (d) and Shannon-Weiner $(\mathrm{H})$ diversity indices Probert concluded that there had been a decline in species variety during the sampling period and an increase in the numerical dominance of certain species. These trends were accompanied by a change from a mollusc-dominated fauna to one dominated by polychaetes and echinoderms, exemplified by a decline in the lamellibranchs Mysella bidentata and Abra alba and an increase in the holothurian Labidoplax digitata. It is instructive to re-examine these data using the analytical methods discussed above. Fig. 18 shows the percent distribution of species in geometric abundance classes for samples taken at approximately $12 \mathrm{wk}$ intervals during the sampling period. As before, the data have been adjusted to numbers $\mathrm{m}^{-2}$ to maintain comparability with other data sets.

This resulted in the amalgamation of abundance Classes I and II. The distribution of species among abundance classes changes in a characteristic way during the course of the sampling period.

The initial sample was taken in April 1970 immediately prior to the reduction in waste output. At this time, the species were distributed in 3 groups along the abundance class axis with the largest number found in the lower abundance classes but with the intermediate Classes V to VII being well represented. By June, some $10 \mathrm{wk}$ after the slurry discharge was reduced, the distribution of abundance classes showed a very different pattern. The relatively rare species had

Table 6. Milford Haven, Pembroke Dock to Popton Point. Species in abundance Classes V and Vl at stations along a transect in the centre of the Haven. (After Addy, 1976)

\begin{tabular}{|c|c|c|c|c|c|}
\hline \multirow{2}{*}{$\begin{array}{c}\text { Geometric } \\
\text { abundance } \\
\text { class }\end{array}$} & \multicolumn{5}{|c|}{ Station number } \\
\hline & 7 & 8 & 5 & 2 & 20 \\
\hline $\begin{array}{c}V \\
(16-31)\end{array}$ & & $\begin{array}{l}\text { Sthenelais boa } \\
\text { Eulalia sanguinea } \\
\text { Pomatoceros triqueter } \\
\text { Nucula nucleus } \\
\text { Amphipod spp. }\end{array}$ & Nephtys sp. & Notomastus latericeus & $\begin{array}{l}\text { Lumbrineris sp. } \\
\text { Audouinia tentaculata } \\
\text { Notomastus latericeus } \\
\text { Melinna palmata }\end{array}$ \\
\hline $\begin{array}{c}\mathrm{VI} \\
(32-63)\end{array}$ & $\begin{array}{l}\text { Anemone sp. } \\
\text { Nucula nucleus }\end{array}$ & $\begin{array}{l}\text { Nephtys sp. } \\
\text { Anemone spp. }\end{array}$ & & Nephtys sp. & Abra alba \\
\hline
\end{tabular}




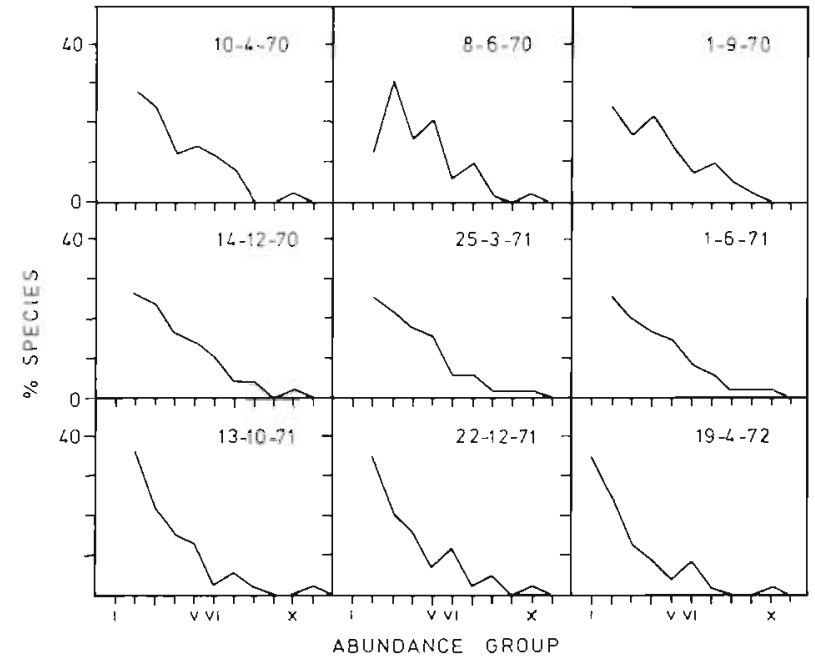

Fig. 18. Distribution of individuals among species for samples taken at approximately $12 \mathrm{wk}$ intervals, $1970-72$, at a station in Mevagissey Bay, Cornwall, following a reduction in discharge of china clay waste. (Data from Probert, 1981). Scales as for Fig. 1

declined markedly and there had been a general shift along the axis towards the higher abundance classes. The pattern was typical of a disturbed community, very irregular, with Classes III and V predominant. Over the ensuing $12 \mathrm{mo}$ this irregular pattem gradually changed to one of an evenly declining distribution along the axis in which the low abundance Classes (I to III), although predominant, never comprised more than $50 \%$ of the species present. During the final 10 mo of the survey a further marked change in distributions became evident, with both the low and high abundance classes becoming better represented at the expense of the intermediate classes, producing a much more skewed distribution along the abundance class axis. The tendency over the 2 yr sampling period was for the community composition to approach gradually a distribution of species abundance similar to the distributions observed in the unpolluted areas of the other surveys described above, i. e. a predominance of relatively rare species, a small number of species with intermediate abundances and 1 or 2 species with high abundances. It seems that these changes represent a progressive response to the reduction in waste input. Therefore an examination of those species occupying the intermediate abundance Classes V and VI at the beginning and end of the survey should reveal species particularly sensitive to these changes.

Table 7 lists these species, and Fig. 19a and b shows the form of their abundance fluctuations over the $2 \mathrm{yr}$ period. These show that species exhibiting 3 differing types of population change have been identified: (a) those that have increased progressively in abundance over the period, e. g. Labidoplax digitata and Philine aperta; (b) those that declined progressively over the period, e. g. Magelona filiformis and Abra alba; and (c) those whose populations fluctuated markedly over the period. Among the latter group is Melinna palmata which initially increased and later decreased over the 2 yr period but with no obvious seasonality to the change, and Tellina fabula, Phaxas pellucidas, Harmothoe lunulata and Acrocnida brachiata all of which showed population growth in the summer, and a decline in winter. However, of these 3 species only $T$. fabula showed similar populations in both summers. Both $P$. pellucidas and A. branchiata were present in much lower numbers in the second summer but $H$. lunulata increased during this period. Of 3 species not figured, Goniada maculata showed a relatively low but stable population throughout the survey period, Montacuta ferruginosa had a low but fluctuating population and Dosinia lupinus was present only at the beginning of the sampling period. Overall, therefore, the species identified as occurring in abundance Classes V and VI at the beginning and end of the survey are not only those generally showing marked population changes throughout the survey but also those exhibiting a range of reactions to progressive changes in environmental conditions.

Table 7. Mevagissey Bay. Species in abundance Classes V and VI at the beginning (April 1970) and end (April 1972) of the survey. (After Probert, 1981)

\begin{tabular}{|c|c|c|}
\hline $\begin{array}{c}\text { Geometric } \\
\text { abundance class }\end{array}$ & $\begin{array}{l}\text { Beginning of survey } \\
\qquad(10-4-70)\end{array}$ & $\begin{array}{l}\text { End of survey } \\
\qquad(19-4-72)\end{array}$ \\
\hline $\begin{array}{c}V \\
(16-31)\end{array}$ & $\begin{array}{l}\text { Glycera (juvenile) } \\
\text { Melinna palmata } \\
\text { Montacuta ferruginosa } \\
\text { Dosinia lupinus } \\
\text { Labidoplax digitata }\end{array}$ & $\begin{array}{l}\text { Nephtys (juvenile) } \\
\text { Goniada maculata } \\
\text { Abra alba } \\
\text { Phaxas pellucidus } \\
\text { Acrocnida brachiata }\end{array}$ \\
\hline $\begin{array}{c}\mathrm{VI} \\
(32-63)\end{array}$ & $\begin{array}{l}\text { Harmothoe lunulata } \\
\text { Magelona filiformis } \\
\text { Philine aperta }\end{array}$ & Tellina fabula \\
\hline
\end{tabular}



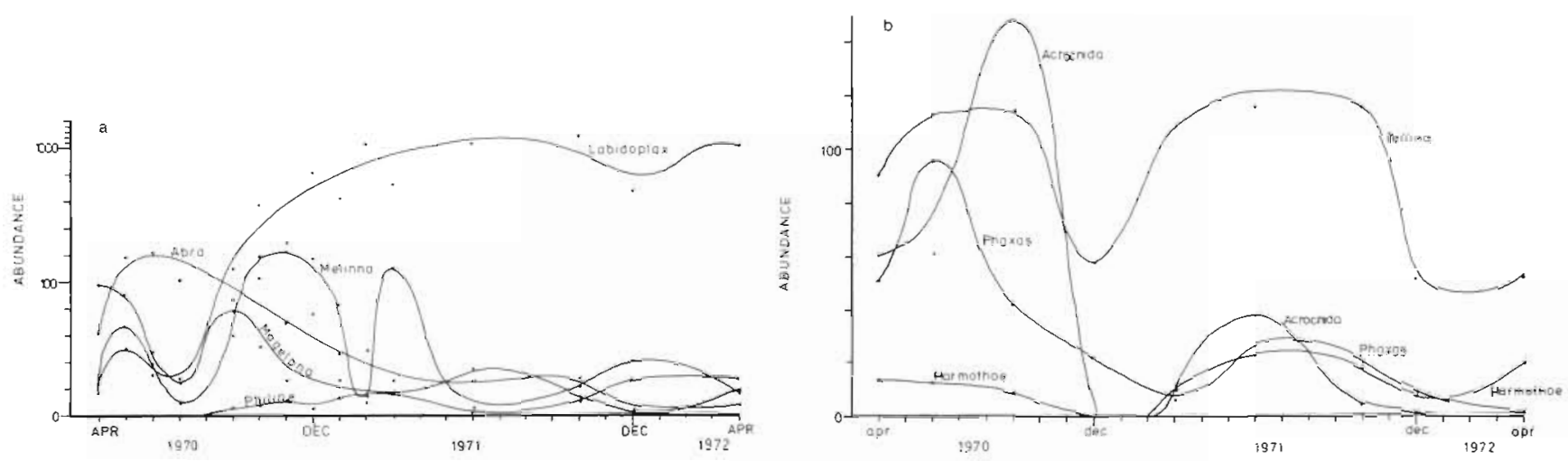

Fig. 19. Changes in abundance of species listed in Table 7 at the station in Mevagissey Bay over a 2 yr period

\section{DISCUSSION}

\section{Distribution of abundance classes}

We have considered in detail analyses of benthic faunal data from 6 different areas subjected to a variety of pollutants from sewage sludge (the Clyde, Bergen), to organic waste (Loch Eil), to general disturbance (Ekofisk), to mixed waste (Milford Haven) and to china clay waste (Mevagissey Bay). In each case the overall trends are similar to those put forward by Gray and Pearson (1982). In an undisturbed area the data show either a smooth right-hand half of a binomial curve where the mode may or may not be exposed, or a series of 2 or 3 binomial curves fairly tightly fused together. The data from the comprehensive surveys at Loch Eil (Fig. 1, LY1), the Clyde (Fig. 2, P1 and P2) and Ekofisk (Fig. 11,6 km stations) show these patterns clearly and are similar to the unpolluted station in Fig. 5 in Gray and Pearson (1982). Whether or not these are representative of log series (mode not exposed) or log-normal distributions has not been analysed, but the fact that where large samples have been taken (Loch Eil and Ekofisk) the mode it exposed suggests that the lognormal is the rule for the benthic communities analysed here and may be a general rule.

At the onset of disturbance, the tendency is for the groups of species - suggested by Ugland and Gray (1982) as underlying all log-normal distributions - to become more exposed as the abundance of species constituting the group move along the abscissa. This trend is most clearly seen in areas with strong pollution gradients, from undisturbed to highly polluted areas (e. g. Loch Eil, Fig. 1 Stn. 70, compared with LY1; or the Clyde, Fig. 4 P5.5, compared with P1 or P9.5 with $\mathrm{P} 3$ and P3.5). In highly polluted areas the plots become very irregular, with a series of peaks (e. g. Clyde Fig. 4 , Stations P7, P7.5, P8, P8.5; Bergen, Fig. 7 Station 19; Milford Haven, Fig. 14 Stations 15, 17, 18, 5 and 8). The changes can only be observed on a comparative basis, however, and the situation met at one single station or sample cannot be explained. Whilst the above-mentioned changes show the response to strong gradients, even weak gradients such as at Ekofisk (Fig. 11) or in Mevagissey Bay (Fig. 18) reveal changes in the form of the abundance classes. The simple plots used here are probably preferable to attempts to constrain the data to a particular distribution such as the log-normal plotting method proposed by Gray and Mirza (1979). Whilst based on the same theoretical principle of a deviation from a fit to a log-normal distribution the method used in this paper is more general.

\section{Sample-size dependence}

Distribution is obviously sample-size dependent in that in the smaller samples many of the rarer species are excluded, i. e. as sample size increases Groups I and II increase. The problem does not appear to be too important as the distribution along the axis of the intermediate and higher groups is not fundamentally affected. The change in form from a single truncated binomial distribution to a broken series of such distributions is apparent even with very incomplete data sets. The data shown in Fig. 3 from transects across the Garroch Head dumping ground in the Clyde suggest that in areas where the gradients are steep a single sample at each point is sufficient to assess population change. Moreover, if for the purpose of comparability the abundances from such samples are scaled up by a factor of 10, thus amalgamating Groups I to IV, the form of the distribution along the axis is not altered.

\section{Selection of indicator species}

The main application of the method, however, is not to detect pollution effects (although this is seen as an 
addition to other techniques already in use), but rather to detect species sensitive to pollution-induced changes. Traditional indicator species used in marine benthic monitoring programmes have been universal opportunists such as Capitella capitata. The reasons why we have rejected opportunist and rare species in suggesting species suitable for monitoring have already been discussed on p. 238.

In our first paper we showed how groups of species could be arrived at simply by recording species occurring in geometric Classes IV to VI. (Some confusion may have arisen in ow lack of clarity in distinguishing between geometric abundance classes and groups of species useful in monitoring in Gray and Pearson, 1982). Here we reserve classes for geometric abundances and groups for species that constitute the binomial curves making up the log-normal distribution of which there are usually 3 or 4 . These groups do not necessarily form ecological units.

In all the areas considered it has been shown that the species present in the intermediate abundance group, here defined as Classes V and VI, are good indicators of population change and generally either increase or decrease markedly in numbers following disturbance to the community. In areas where previous assessment had listed species indicative of polluted conditions such species are generally found in Classes $\mathrm{V}$ and VI along the abundance axis under mildly polluted conditions. These observations suggest that species occurring in benthic samples at abundances between 16 and
$64 \mathrm{~m}^{-2}$ should be considered as potentially useful indicators of polluted conditions. In the assessment of the data list for the possible signs of distortion caused by either a pollutant effect or a natural stress, the rare and the very abundant species may be discounted initially and attention focussed on the groups of species with intermediate abundances.

It is apparent from the data analyses discussed above that a number of genera occur in the intermediate abundance group across many of the data sets, and appear to attain a degree of ubiquity in the different samples. In some cases species are common to 2 or 3 areas, e. g. Pholoe minuta is common to Bergen, the Clyde and Loch Eil, and Scoloplos armiger is common to Loch Eil, Bergen, Ekofisk and Angle Bay. A list of species common to more than one area is shown in Table 8 . This closer examination reveals that although many genera are in common, only in exceptional cases are species present in more than 2 of the 6 areas considered. This is to be expected from knowledge of zoogeographical species distributions. In certain areas there will be a characteristic species group, useful in a monitoring context, differing from that of other areas. The possibility of fingerprinting a small range of ubiquitous indicator species is therefore rejected, even from a relatively similar range of environments. Nevertheless, the suggested method of selecting those species present in the intermediate abundance group from among samples where the distribution of species along the log-normal axis first shows distortion of the

Table 8. List of species which appeared in abundance Classes V and VI in more than one of the areas discussed

\begin{tabular}{|c|c|c|c|c|c|c|c|c|}
\hline \multirow[b]{2}{*}{ Species } & \multirow[b]{2}{*}{$\begin{array}{l}\text { Lynn } \\
\text { of } \\
\text { Lorne }\end{array}$} & \multirow[b]{2}{*}{$\begin{array}{c}\text { Loch } \\
\text { Eil }\end{array}$} & \multirow[b]{2}{*}{$\begin{array}{l}\text { Firth } \\
\text { of } \\
\text { Clyde }\end{array}$} & \multicolumn{2}{|c|}{ Areas } & \multirow[b]{2}{*}{$\begin{array}{c}\text { Angle } \\
\text { Bay }\end{array}$} & \multirow[b]{2}{*}{$\begin{array}{l}\text { Inner } \\
\text { Haven }\end{array}$} & \multirow[b]{2}{*}{$\begin{array}{c}\text { Mevag- } \\
\text { issey } \\
\text { Bay }\end{array}$} \\
\hline & & & & $\begin{array}{l}\text { Bergen } \\
\text { Fjords }\end{array}$ & $\begin{array}{l}\text { North } \\
\text { Sea }\end{array}$ & & & \\
\hline Lumbrineris sp. & * & & * & & & * & • & \\
\hline Pholoe minuta & & * & * & * & & & & \\
\hline Glycera alba & & * & * & * & * & & & \\
\hline Goniada maculata & & $\cdot$ & & • & $*$ & & & • \\
\hline Diplocimus glaucus & & $*$ & & • & & & & \\
\hline Scoloplos armiger & & • & & $\cdot$ & * & * & & \\
\hline Anaitides groenlandica & & * & & $*$ & & & & \\
\hline Chaetozone setosa & & & • & - & & & & \\
\hline Melinna palmata & & & • & & & • & * & • \\
\hline Owenia fusiformis & & & & - & • & & & \\
\hline Notomastus latericeus & & & & & & & • & - \\
\hline Nephtys incisa & & & & & $*$ & & • & \\
\hline Eteone longa & & & • & - & & & & \\
\hline Nucula sulcata & * & & • & & & & & \\
\hline Abra alba & • & & • & & & • & • & - \\
\hline Nuculana minuta & & & • & • & & & & \\
\hline Nucula tumidula & & & & * & & & * & \\
\hline Amphiura chiajei & $=$ & & & * & & & & \\
\hline Harmothoe sp. & & & • & & & & & - \\
\hline Philine aperta & & & - & & & & & - \\
\hline
\end{tabular}


usual truncated binomial curve, appears to provide an objective method of identifying species likely to be useful indicators of population change in any particular area.

To summarize again, the advantages of the method are: it is rapid and easy involving no real computation; it is robust, i. e. it can be used across a range of sample sizes; it is theoretically sound; it allows (a) a comparative assessment of the degree of stress-related distortion of the abundance pattern of species in a community with a higher degree of sensitivity than diversity indices, and (b) an objective selection of species that are useful indicators of pollutant effects.

\section{Publication of data sets}

In compiling information for this comparative study it has been necessary to search the published literature for suitable data sets to analyse. This exercise proved particularly frustrating because of the very few publications in which raw survey data appear. No doubt, because of the cost of printing complete data sets such information is rarely included in the published version of benthic surveys. This makes subsequent re-analysis impossible and greatly reduces the utility of the publication. We here append a plea for authors and editors to consider means by which full lists of raw data from community surveys can be made available.

Acknowledgements. The 2 papers comprising this communication were developments from hypotheses put forward, discussed and tested at the Nordic Marine Biology Course held in Bergen, Norway, in June 1981. The authors acknowledge the invaluable assistance of Torliev Brattegard who organised the course and of the enthusiastic group of students who took part. We also thank Howard Feder and John Hartley for critical reading of our original draft, and 3 anonymous reviewers for criticism.

\section{LITERATURE CITED}

Addy, J. M. (1976). Preliminary observations of the sublittoral macrofauna of Milford Haven. In: Baker, J. M. (ed.) Marine ecology and oil pollution. Applied Science Publishers, Barking, Essex, p. 91-130

Blackstock, J. (1980a). A biochemical approach to assessment of effects of organic pollution on the metabolism of the non-opportunistic polychaete Glycera alba. Helgoländer Meeresunters. 33: 546-555
Blackstock, J. (1980b). Estimation of activities of some enzymes associated with energy yielding metabolism in the polychaete Glycera alba (Müller) and the application of the methods to the study of the effect of organic pollution. J. exp. mar. Biol. Ecol. 46: 197-217

Dicks, B. (1976). Offshore biological monitoring. In: Baker, J. M. (ed.) Marine ecology and oil pollution. Applied Science Publishers, Barking, Essex, p. 325-430

Grassle, J. P., Grassle, J. F. (1976). Sibling species in the marine pollution indicator Capitella (Polychaeta). Science, N. Y. 192: 567-569

Gray, J. S., Mirza, F. B. (1979). A possible method for the detection of pollution-induced disturbance on marine benthic communities. Mar. Pollut. Bull. 10: 142-146

Gray, J. S., Pearson, T. H. (1982). Objective selection of sensitive species indicative of pollution-induced change in benthic communities. 1. Comparative methodology. Mar. Ecol. Prog. Ser. 9: 111-119

Howell, B. R., Shelton, R. G. J. (1970). The effect of china clay on the bottom fauna of St. Austell and Mevagissey Bays. J. mar. biol. Ass. U. K. 50: 593-607

Johannessen, P. J. (1981). Overvåking av fjordene rundt Bergen 1979-1980. Rapport Nr. 1. Statlig program for forurensningsovervåking. Bergen Kommune, p. 1-108

Krebs, C. J. (1972). Ecology. Harper and Row, New York

Pearson, T. H. (1975). The benthic ecology of Loch Linnhe and Loch Eil, a sea-loch system on the west coast of Scotland. IV. Changes in the benthic fauna attributable to organic enrichment. J. exp. mar. Biol. Ecol. 20: 1-41

Pearson, T. H. (1982a). The Loch Eil project: population fluctuations in the macrobenthos. J. exp. mar. Biol. Ecol. 56: 305-321

Pearson, T. H. (1982b). The Loch Eil project: assessment and synthesis with a discussion of certain biological questions arising from a study of the organic pollution of sediments. J. exp. mar. Biol. Ecol. 57: 93-124

Pearson, T. H. (1982c). Ecological principles and biochemical indices. In: Actualities de biochimie marine. Publ. CNEXO (Actes Collg.) 14: 423-434

Pearson, T. H., Rosenberg, R. (1978). Macrobenthic succession in relation to organic enrichment and pollution of the marine environment. Oceanogr. mar. biol. A. Rev. 16: 229-311

Portmann, J. E. (1970). The effect of china clay on the sediments of St. Austell and Mevagissey Bays. J. mar. biol. Ass. U. K. 50: 577-591

Preston, F. W. (1962). The canonical distribution of commonness and rarity. Ecology 43: 185-215

Probert, P. K. (1975). The bottom fauna of china clay waste deposits in Mevagissey Bay. J. mar. biol. Ass. U. K. 55: $19-44$

Probert, P. K. (1981). Change in the benthic community of china clay waste deposits in Mevagissey Bay following a reduction of discharges. J. mar. biol. Ass. U. K. 61: 789-804

Ugland, K. I, Gray, J. S. (1982). Log-normal distributions and the concept of community equilibrium. Oikos 39: 171-178 